\title{
Study of the osmotic regulation processing in the juvenile Persian sturgeon, Acipenser persicus. Borodin, 1897 in transfer directly to the Caspian seawater
}

\begin{abstract}
The aim of this study was to transfer directly juvenile Acipenser persicus from freshwater to the Caspian Seawater (CSW). The fish in different age and size (weight (W) \& length (L)) groups (I: 35 days, W: $2.75 \pm 0.15 \mathrm{~g} \&$ L: $7.93 \pm 0.47 \mathrm{~cm}$; II: 50 days, W: $3.15 \pm 0.12 \mathrm{~g} \& \mathrm{~L}$ : $8.31 \pm 0.28 \mathrm{~cm}$; III: 65 days, W: $4.33 \pm 0.12 \mathrm{~g} \& \mathrm{~L}: 9.39 \pm 0.29 \mathrm{~cm} ; \mathrm{n}=90$ for each group) and in two different saline water (FW: $<0.5 \%$ and CSW: $12.5 \%$ ) were investigated. The fish were transferred directly from FW to CSW. After 168 hours, blood samples were taken from the fish. The results showed that the survival in all groups in CSW was from $56 \%$ up to $76 \%$ and increased with increasing age and weight of fish. Some hematological parameters and levels of cortisol, osmolarity and ion concentration $\left(\mathrm{Na}^{+}, \mathrm{K}^{+}, \mathrm{Ca}^{+2}\right.$ and $\left.\mathrm{Mg}^{+2}\right)$ in the plasma were determined. The functional levels of the mechanism of osmotic and ionic homeostasis were similar in all groups $(\mathrm{P}>0.05)$ but differed in experimental media $(\mathrm{P}<0.05)$. Significant differences were observed between the levels of plasma ion concentrations in different media $(\mathrm{P}<0.05)$. Plasma $\mathrm{Na}^{+}, \mathrm{K}^{+}$and $\mathrm{Ca}^{+2}$ concentrations were higher than those of $\mathrm{FW}$ media, but lower than in Brackish water media $(\mathrm{P}<0.05)$. Plasma $\mathrm{Mg}^{+2}$ concentrations were lower than those of FW and Brackish water media $(\mathrm{P}<0.05)$. The Hct, $\mathrm{Hb}, \mathrm{MCV}, \mathrm{MCH}$ and plasma osmolarity decreased and MCHC and plasma cortisol levels increased with increasing salinity $(\mathrm{P}<0.05)$. But the number of $\mathrm{WBC}$ and $\mathrm{RBC}$ did not change $(\mathrm{P}<0.05)$ and reached a stable state. Therefore, it is possible to release juvenile sturgeon directly from FW to CSW with increasing weight and age.
\end{abstract}

Keywords: acipenser pesicus, hematological parameters, ion, cortisol, osmolarity
Volume 10 Issue 2 - 2021

\author{
SMVahid Farabi, M Bahmani, M Golaghaei \\ Darzi \\ Ministry of Jihad -e- Agriculture, Agricultural Iranian Fisheries \\ Science Research Institute (IFSRI), Caspian Sea \\ Ecology Research Center (CSERC), Iran
}

\author{
Correspondence: SMVahid Farabi, Department of \\ Aquaculture, CSERC, IFSRI, Iran, \\ Email Smv_Farabi@hotmail.com
}

Received: March 08, 202I | Published: March 26, 2021

\section{Introduction}

In the current situation, it is necessary to restore the sturgeon stocks of the Caspian Sea. Because sturgeon fishing has declined sharply over a 110 -year period leading up to 2006 , from 29.8 to 0.38 thousand tonnes. ${ }^{1}$ The declining trend of fishing and exploitation of sturgeon in the Caspian Sea continues continuously. Because the existing threats, including river pollution, overfishing continue. ${ }^{2}$

On the other hand, one of the main problems in fish stock regeneration activities is the loss of juvenile fish due to artificial reproduction during release into the natural environment. Most juvenile deaths occur when entering the wild. ${ }^{3,4,5}$ Studies by Sanchez et al. $^{6}$ showed that one of the important indicators of success or failure in the process of tolerance to environmental salinity and ionosmotic regulation is the survival rate of fish according to age and size6. Various scientists around the world have studied the ionic and osmotic regulation of fish. In these studies, hematological, serum and hormonal parameters along with measurement of serum ions and plasma osmolarity were generally examined. Numerous studies have also been performed on sturgeon, for example: in Huso huso, A. persicus, A. gueldenstaedti, A. stellatus, A. nudiventris from Caspian $\mathrm{Sea}^{7-12}$ in $A$. transmontanus, ${ }^{13}$ in $A$. naccari ${ }^{14,6}$ in $A$. bravirostrum and A. oxyrhynchus. ${ }^{15,16}$ The aim of the present study was to investigate the osmotic and ionic regulation of A. persicus juveniles from artificial reproduction of sturgeon propagation centers for direct release into the Caspian Sea.

\section{Materials and methods}

In the direct transfer of fish from fresh water to seawater, some hematological, serum, hormonal and ion-osmotic indices in Acipenser persicus, of different groups (I: 35days, BW: $2.75 \pm 0.15 \mathrm{~g}$, TL: $7.93 \pm 0.47 \mathrm{~cm}$; II: 50 days, BW: $3.15 \pm 0.12 \mathrm{~g}$, TL: $8.31 \pm 0.28 \mathrm{~cm}$; III: 65days, BW: $4.33 \pm 0.12 \mathrm{~g}$, TL: $9.39 \pm 0.29 \mathrm{~cm})$ in freshwater $(\mathrm{FW}:<$ $0.5 \%$ ) and the Caspian Seawater (CSW: $12.5 \%$ ) were investigated (Figure 1).

Each group consisted of 90 fish in three experimental units $(\mathrm{n}=30)$. The fishes were directly transferred from $\mathrm{FW}$ to $\mathrm{C}_{\mathrm{S}} \mathrm{W}$. The possible repercussions of ion-osmoregulatory processes on some classical indicators were examined at the end of 168 hours' fish salinity tolerance. Blood cell count (Red blood cells: RBC, white blood cells: WBC), blood parameters (hemoglobin concentration: $\mathrm{Hb}$, hematocrit: Hct) were measured by microscope and haemocytometers (standard Neubauer cell counting chamber) over cells suspended in Rees-Escher's solution. The Hct were measured at $16329.6 \mathrm{~g}$ for 5min in a clinical centrifuge (Hettich-D7200 Tuttlingen: Germany). The hemoglobin concentration $(\mathrm{Hb})$ was determined using the cyanmethemoglobin method with spectrophotometry (CECILCE1020: Germany) at 540nm Some blood parameters were calculated by the following equations. ${ }^{18,19}$

Mean cell volume $(\mathrm{MCV})=\mathrm{Hct}^{*} 10^{*} \mathrm{RBC}^{-1}$ 
Mean cell hemoglobin concentration $(\mathrm{MCHC})=\mathrm{Hb}^{*} 100 * \mathrm{Hct}^{-1}$

Amount of hemoglobin per erythrocyte $(\mathrm{MCH})=\mathrm{Hb}^{*} 10 * \mathrm{RBC}^{-1}$

The plasma samples were extracted from fish blood by centrifugation (Hettich-D7200 Tuttlingen: Germany) at 453.6g for $5 \mathrm{~min}$ and then stored at $-20^{\circ} \mathrm{C}$. After plasma defrosting, ion concentrations $(\mathrm{Na}+, \mathrm{K}+$ : by flame photometer Corning $405 \mathrm{C}$ : IRI; $\mathrm{Ca}^{2}+$ and $\mathrm{Mg}^{2}+$ : by with an absorption spectrophotometer UNICO 3115233: USA), cortisol (with competitive enzyme immunoassay and automatic instrument for ELISA kits on microplate), and osmolarity (cryoscopy method by (Roebling Nr.9610003. Type 13: Germany) were measured ${ }^{18,19}$ (Figure 2).
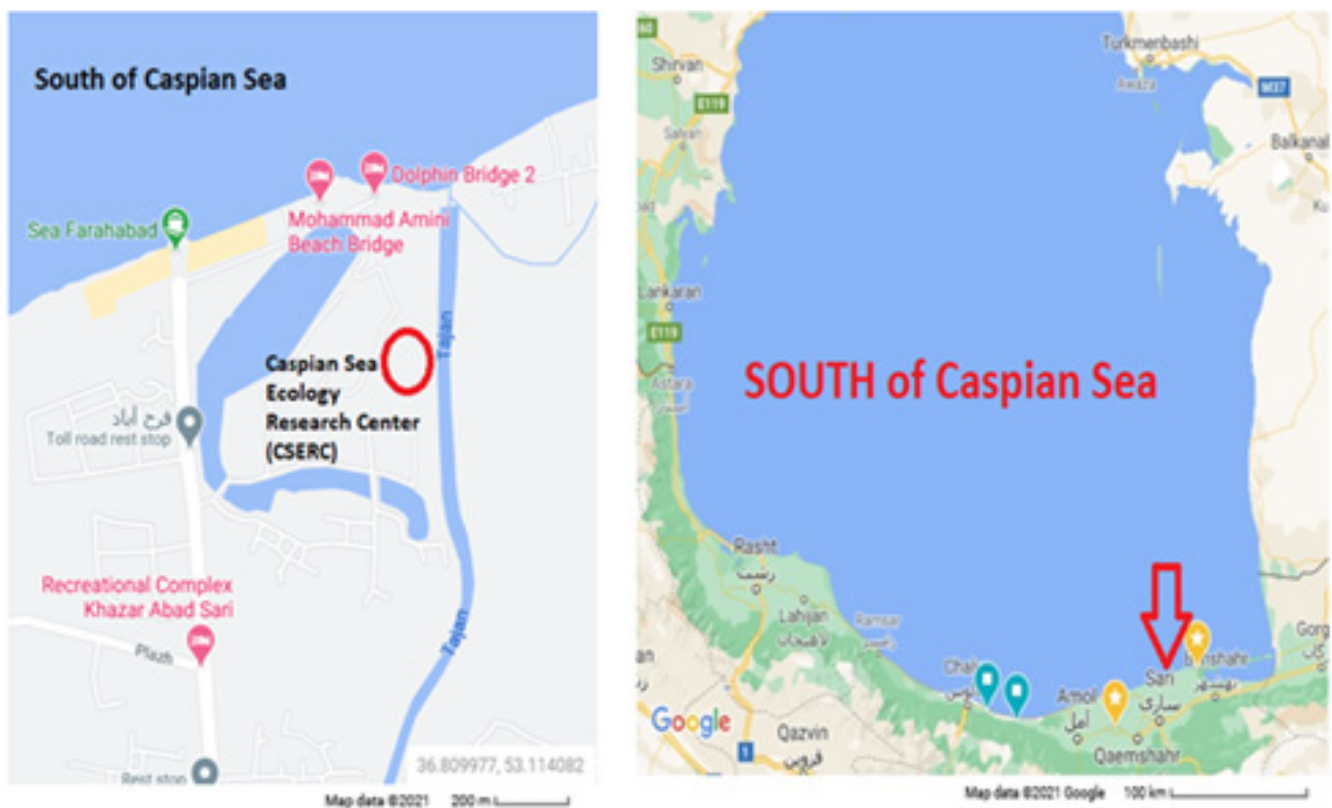

Figure I Location of studies in the Caspian Sea Ecology Research Center in the southern region of the Caspian Sea.
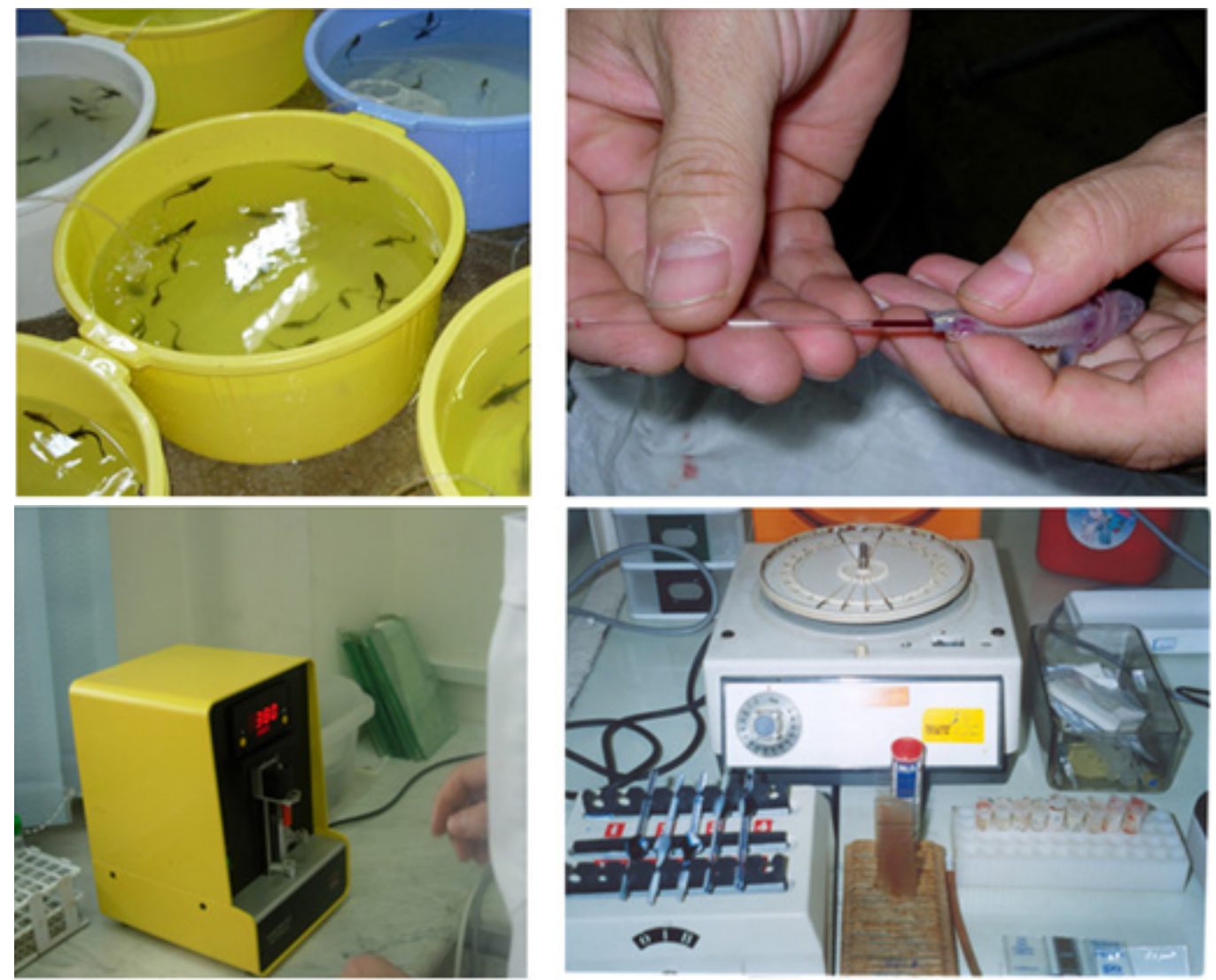

Figure 2 Experimental treatments and hematology laboratory of the Caspian Ecological Research Center. 


\section{Results}

Three age groups (35, 50 and 65 days) were compared to determine the survival rate and salinity stress tolerance. Fresh water was the control group. The results showed that the experimental groups had more than 56\% survival after 168 hours. Therefore, mortality was not observed higher than $44 \%$ in all groups in $\mathrm{C}_{\mathrm{S}} \mathrm{W}$. Survival rate was increased with increasing fish age in $\mathrm{C}_{\mathrm{S}} \mathrm{W}$ (Figure 3).

The results of counting blood cells and measuring and calculating blood indices, cortisol levels and plasma osmolarity are shown in Table 1. Also, the concentration values of blood plasma ions and environmental water of fish are shown in Table 2.
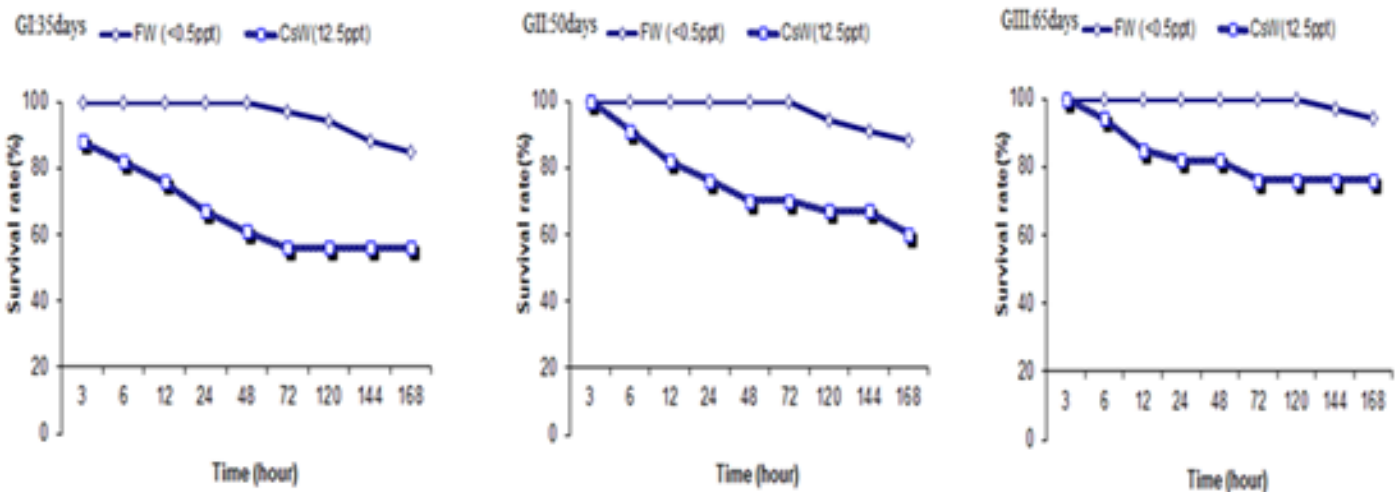

Figure 3 The survival rate of Persian sturgeon in 35, 50, and 65-day ages, in transfer directly from freshwater to the Caspian Seawater.

Table I Hematological parameters, concentration of cortisol and osmolarity in blood plasma of juveniles' Acipenser persicus after acclimation for 168 hours to different media

\begin{tabular}{|c|c|c|c|c|c|c|c|c|c|}
\hline \multirow{2}{*}{$\begin{array}{l}\text { Juvenile's } \\
\text { group: } \\
n=10\end{array}$} & $\begin{array}{l}\text { Hct } \\
\%\end{array}$ & $\begin{array}{l}\text { RBC } \\
10^{3} \text { cellsul|-1 }\end{array}$ & $\begin{array}{l}\text { WBC } \\
10^{3} \text { cellsul|- }\end{array}$ & $\begin{array}{l}\mathrm{Hb} \\
\mathrm{g} / \mathrm{dl}\end{array}$ & $\begin{array}{l}\text { MCV } \\
\mathrm{fl}\end{array}$ & $\begin{array}{l}\mathrm{MCH} \\
\text { pg }\end{array}$ & $\begin{array}{l}\mathrm{MCHC} \\
\%\end{array}$ & $\begin{array}{l}\text { Cortisol } \\
\mathrm{ng} / \mathrm{ml}\end{array}$ & $\begin{array}{l}\text { Osmolarity } \\
\text { mOsml/l }\end{array}$ \\
\hline & \multicolumn{9}{|c|}{ In FW: $<0.5 \%$ and Osmolarity: $5 \pm 2 \mathrm{mOsml} / \mathrm{l}$} \\
\hline 1.35 days & $38.80 \pm 2.86$ & $679.02 \pm 75.93$ & $12.90 \pm 2.54$ & $5.10 \pm 0.53$ & $565.52 \pm 27.28^{\mathrm{b}}$ & $74.08 \pm 1.31^{c}$ & $13.12 \pm 0.59^{b}$ & $18.74 \pm 0.92$ & $241.50 \pm 3.34$ \\
\hline II.50days & $38.80 \pm 3.01$ & $679.21 \pm 71.71$ & $|3.45 \pm 2.3|$ & $5.10 \pm 0.56$ & $573.36 \pm 26.38^{\mathrm{b}}$ & $75.11 \pm 2.7 I^{\mathrm{bc}}$ & $13.12 \pm 0.73^{b}$ & $18.87 \pm 0.50$ & $243.04 \pm 3.13$ \\
\hline III .65days & $38.80 \pm 2.03$ & $639.39 \pm 80.20$ & $14.53 \pm 1.43$ & $5.36 \pm 0.39$ & $611.48 \pm 40.04^{\mathrm{a}}$ & $84.42 \pm 5.74^{\mathrm{a}}$ & $13.81 \pm 0.49^{a}$ & $18.81 \pm 0.62$ & $240.60 \pm 4.22$ \\
\hline \multicolumn{10}{|c|}{$\mathrm{C}_{\mathrm{s}} \mathrm{W}: \mathrm{I} 2.5 \%$ and Osmolarity: $407 \pm 2.92 \mathrm{mOsml} / \mathrm{l}$} \\
\hline 1.35 days & $21.80 \pm 1.87$ & $668.12 \pm 69.25^{a}$ & $13.50 \pm 1.50$ & $5.18 \pm 0.57$ & $327.10 \pm 15.41^{\mathrm{b}}$ & $77.63 \pm 5.43^{b}$ & $23.72 \pm 0.92 \mathrm{ab}$ & $31.24 \pm 1.29$ & $297.30 \pm 4.79$ \\
\hline II.50days & $21.90 \pm 2.18$ & $662.32 \pm 19.32^{\mathrm{b}}$ & $13.05 \pm 1.70$ & $5.28 \pm 0.62$ & $35 \mathrm{I} .48 \pm 25.27^{\mathrm{a}}$ & $84.69 \pm 7.62^{\mathrm{a}}$ & $24.08 \pm 1.15^{\mathrm{a}}$ & $31.66 \pm 0.70$ & $296.10 \pm 4.15$ \\
\hline III .65days & $21.80 \pm 2.2$ & $\underset{\text { ab }}{623.21 \pm 34.66}$ & $13.15 \pm 0.82$ & $5.02 \pm 0.72$ & $343.75 \pm 19.46^{\mathrm{ab}}$ & $79.04 \pm 8.06^{\mathrm{ab}}$ & $22.95 \pm 1.35^{b}$ & $31.82 \pm 0.89$ & $295.00 \pm 5.73$ \\
\hline
\end{tabular}

Note:The Values with different superscript and subscript letters are significantly difference in age and size classes of different in each experimental media within each column (Means SD and $\mathrm{p}<0.05$ )

Table 2 lon concentration of blood plasma in juveniles' Acipenser persicus and environment water after fish acclimation to different salinity for 168 hours. (Means \pm SD)

\begin{tabular}{|c|c|c|c|c|c|c|c|c|}
\hline \multirow{3}{*}{$\begin{array}{l}\text { Juvenile's } \\
\text { group: } n=10\end{array}$} & \multicolumn{4}{|c|}{ In Fresh Water: <0.5 \%。 } & \multicolumn{4}{|c|}{ In Caspian Sea Water: I 2.5 \%。 } \\
\hline & \multicolumn{4}{|c|}{ Ion Concentration mEq/l } & \multicolumn{4}{|c|}{ Ion Concentration mEq/l } \\
\hline & $\mathrm{Na}^{+}$ & $\mathbf{K}^{+}$ & $\mathrm{Ca}^{2+}$ & $\mathbf{M g}^{2+}$ & $\mathrm{Na}^{+}$ & $\mathbf{K}^{+}$ & $\mathrm{Ca}^{2+}$ & $\mathbf{M g}^{2+}$ \\
\hline I.35days & $124.90 \pm 1.37^{\mathrm{a}}$ & $1.81 \pm 0.05^{a}$ & $4.84 \pm 0.09^{a}$ & $0.62 \pm 0.02^{b}$ & $151.32 \pm 1.16^{\mathrm{b}}$ & $2.03 \pm 0.05^{b}$ & $5.56 \pm 0.09^{b}$ & $1.75 \pm 0.05^{b}$ \\
\hline 11.50 days & $125.10 \pm 2.02^{\mathrm{a}}$ & $1.79 \pm 0.06^{\mathrm{a}}$ & $4.86 \pm 0.09^{a}$ & $0.65 \pm 0.13^{b}$ & $|5| .33 \pm\left. 2.2\right|^{\mathrm{b}}$ & $2.02 \pm 0.04^{b}$ & $5.57 \pm 0.07^{\mathrm{b}}$ & $1.77 \pm 0.09 \mathrm{~b}$ \\
\hline III .65days & $124.13 \pm 3.11^{\mathrm{a}}$ & $1.83 \pm 0.06^{\mathrm{a}}$ & $4.88 \pm 0.0 \mathrm{I}^{\mathrm{a}}$ & $0.63 \pm 0.06^{b}$ & $152.50 \pm 2.88^{b}$ & $2.03 \pm 0.05^{b}$ & $5.54 \pm 0.05^{b}$ & $1.74 \pm 0.06^{\mathrm{b}}$ \\
\hline Water: $n=5$ & $28.84 \pm 2.86^{\mathrm{b}}$ & $0.39 \pm 0.03^{b}$ & $2.04 \pm 0.15^{b}$ & $1.11 \pm 0.16^{a}$ & $175.88 \pm 4.56^{a}$ & $2.4 I \pm 0.35^{a}$ & $20.46 \pm 0.82^{a}$ & $63.3 \pm 3.06^{\mathrm{a}}$ \\
\hline
\end{tabular}

Note:The values with different letter (between groups and water) within each column have shown significantly difference ( $\mathrm{p}<0.0 \mathrm{I})$

The osmotic and ionic regulation were shown in all groups and differed in experimental waters $(\mathrm{P}<0.05)$. Significant differences were observed between the levels of plasma ion concentrations in different waters $(\mathrm{P}<0.05)$. The plasma level of $\mathrm{Na}^{+}, \mathrm{K}^{+}$, and $\mathrm{Ca}^{+2}$ ions were higher than those of $\mathrm{FW}$ but lower than in $\mathrm{CsW}(\mathrm{P}<0.05)$. The plasma level of $\mathrm{Mg}^{+2}$ ion was lower than those of FW and $\mathrm{CsW}(\mathrm{P}<0.05)$. The Hct, $\mathrm{Hb}, \mathrm{MCV}, \mathrm{MCH}$, and plasma osmolarity were decreased with increasing salinity. The MCHC and plasma cortisol levels were increased with increasing salinity $(\mathrm{P}<0.05)$. The number of WBC and $\mathrm{RBC}$ did not change in different waters $(\mathrm{P}<0.05)$. 


\section{Discussion}

Based on our data and that of others ${ }^{17,15,10}$ there is a good similarity in $\mathrm{Na}^{+}, \mathrm{K}^{+}, \mathrm{Ca}^{+2}$, and $\mathrm{Mg}^{+2}$ ions concentrations between $\mathrm{FW}$ and $\mathrm{C}_{\mathrm{S}} \mathrm{W}$ and adapted sturgeon, indicating an osmotic and ionic regulation.

After direct transfer of fish from $\mathrm{FW}$ to the $\mathrm{CsW}$, the plasma $\mathrm{Na}^{+}$ concentrations of fish were determined to be higher than fresh water and less than the saline water. Also, Plasma $\mathrm{Mg}^{+2}$ concentrations $(1.86 \pm 0.02 \mathrm{mEq} / \mathrm{l})$ were determined much lower than Caspian Sea water $(63.3 \pm 3.06 \mathrm{mEq} / \mathrm{l})($ Table 2$)$. These results are similar to the results of other researchers on the plasma concentrations of adapted sturgeon in salt water. ${ }^{10,17,22}$

Death is the ultimate biological consequence of environmental change. In fish that did not achieve ionic and osmotic compatibility under salinity stress in the Caspian Sea water, fish death occurred. ${ }^{23}$ In this survey, the survival rate with increased size (and age) was increased.

Some authors suggest that there is no correlation between body size and hematological parameters such as Hct, erythrocyte size and number, and hemoglobin concentration. ${ }^{24,25}$ This is supported by the results of the present study in deferent size and age juvenile $A$. persicus. But, the Hct, $\mathrm{MCV}$ decreased and $\mathrm{MCHC}$ increased in $\mathrm{FW}$ compared to $\mathrm{C}_{\mathrm{S}} \mathrm{W}(\mathrm{p}<0.05)$, and $\mathrm{Hb}, \mathrm{MCH}, \mathrm{RBC}$ and $\mathrm{WBC}$ did not change ( $>0.05)$, (Table 1).

Martinez -Álvarez et al. ${ }^{23}$ and Plaut indicate that these changes depend on the volume of water in the blood and are influenced by changes in environmental salinity. ${ }^{23}$

In this study, in the direct transfer of fish to brackish water, the number of fish blood cells did not change. But their red blood cell volume dropped. For this reason, this change can be related to the water volume of fish blood in brackish water. The results of this study are similar to with Tajan and Zohrabi research on some hematological and biochemical parameters of Cultured Stellate sturgeon (Acipenser stellatus) and Ship sturgeon (Acipenser nudiventris). ${ }^{26}$

The cortisol is the most important hormone in fish ionosmoregulation in saltwater. Cortisol has been shown to influence the movement of sodium ions across the gill, in both fresh-water-adapted and seawater- adapted eels..$^{27,28}$ The increase of plasma cortisol levels is considered to be a primary indicator of the stress response. In the present study, the trend of increasing levels of cortisol at higher salinity in juvenile $A$. persicus (Table 1) were similar to chondrostean. ${ }^{23,26,29}$

However, blood parameters and levels of cortisol, osmolarity, and ion concentration values in $\mathrm{CsW}$ did not return to initial values in FW. The result has been shown that the osmoregulation system caused physiological changes in this species. Therefore, it is possible to release juvenile sturgeon directly from FW to CSW with increasing weight and age.

\section{Conclusion}

As a result, due to the increasing pollution of rivers in the southern region of the Caspian Sea, it is not possible to release juvenile's sturgeon into the river environment (fresh water). On the other hand, it is not possible to rehabilitate rivers in the current situation due to the need for high financial resources and the social conditions of the coastally people. For this reason, according to the results of this study, the juvenile's sturgeon obtained from artificial reproduction in the sturgeon propagation centers of Iran can be released directly into the sea. In this method, the survival of the fish will increase with increasing weight and age.

\section{Conflicts of interest}

The author declares that there are no conflicts of interest.

\section{Funding}

Iranian Fisheries Science Research Institute (IFSRI), Caspian Sea Ecology Research Center (CSERC).

\section{Acknowledgments}

We are grateful to all our colleagues in the Shaheed Marjani Sturgeon Propagation Center and Caspian Sea Ecology Research Center.

\section{References}

1. Pourkazemi M. Caspian Sea Sturgeon Conservation and Fisheries: Past, Present and Future. Journal of Applied Ichthyology. 2006;22 (1):12-16.

2. Adeli A. Evaluation and management of sturgeon exploitation on the Iranian shores of the Caspian Sea (1928- 2016). Iranian Journal of Fisheries. 2018;27(1).

3. Olla BL, Davis MW, Ryer CH. Understanding how the hatchery environment represses or promotes the development of behavioural survival skills. Bulletin of Marine Science. 1998;62:531-550.

4. Heggberget TG, Staurnes M, Strand R et al. Smoltification in salmonids. NINA Norsk Institutt for Naturforskning Forsknings rapport. 1992;31:342.

5. Suboski MD, Templeton JJ. Life skills training for hatchery fish: social learning and survival. Fisheries Research (Amsterdam). 1989. 7(4):343352.

6. Sanchez de Lamadrid, A, Garcia-Gallego M, Sanz A, et al. Acclimation of the sturgeon, Acipenser naccarii Bonaparte 1836, to saltwater: Effect of age and weight. 1998; $6 \mathrm{p}$.

7. Krayushkina LS. Ionic composition of blood serum and state of chloridesecreting cells of beluga, Huso huso, and skate, Dasyatis pastinaca, during their adaptation to hypertonic media. In: Physiology and Biochemistry of Lower Vertebrata. Editor. EM Kreps. Leningrad: Science. 1974;18-23.

8. Krayushkina LS, Kiseleva SG, Moiseenki SN. Functional changes in thyroid gland and chloride cells of gills during adaptation of young beluga, Huso huso, to hypertonic environment. J. Ichthyol. 1976;16:834-841.

9. Krayushkina LS, Panov AA, Gerasimov AA, et al. Changes in sodium, calcium and magnesium ion concentrations in sturgeon (Huso huso) urine and in kidney morphology. J Comp.Physiol B. 1996;165:527-533.

10. Krayushkina LS, Semenova OG. Osmotic and ion regulation in different species of acipenserids (Acipenseriformes, Acipenseridae). J. Ichthyol. 2006;46(1):108-119.

11. Kazemi R, Bahmani M, Krayushkina LS, et al. Changes in blood serum osmolarity and ultrastracture of gill chloride cells in young Persian sturgeon A. persicus (Borodin) of different sizes during adaptation to sea water. Zoological Poloniae . 2003;48/1-4:5-30.

12. Keshtkar Langerudi E, Jamili Sh, Ramezani-Fard E, et al. Osmoregulation, endocrine capability, and histopathological alteration of starry sturgeon (Acipenser stellatus) fry after transfer to Brackish Water. Iranian Journal of Fisheries Sciences. 2020;6.

13. McEnroe M, Cech J. Osmoregulation in juvenile and adult white sturgeon, Acipenser transmontanuos. Environm Biol Fishes, 1985;14:23-30.

14. Cataldi E, McKenzie D, Di Marco P et al. Some aspects of osmotic and ionic regulation in Adriatic sturgeon blood: Journal of Applied Ichthyology, 1997;15(4-5):57-60

15. Krayushkina LS. Characteristics of osmotic and ionic regulation in marine diadromous sturgeon Acipenser brevirostrum and A. oxyrhynchus (Acipenseridae). J Ichthyol. 1998;38(8):660-668. 
16. Krayushkina LS, Gerasimov AA, Smirnova AV. Hypo-osmotic regulation and peculiarities of morphological-functional condition of kidney and gill chloride cells in diadromous marine sturgeons. Reports of the Russian Academy of Sciences. 2001;378(3): 503-509.

17. Farabi SMV, Hajimoradloo A, Bahmani M. Salinity tolerance and some physiological indicators of ion-osmoregulatory system in juvenile Ship Acipenser nudiventris (Lovetsky, 1828) in the south of Caspian Sea: Effect of age and size. International Workshop on Adveced Techniques in Sturgeon Fish Larviculture. 2007;128-135.

18. Ameri Mahabadi M. Veterinary clinical hematology methods, Tehran University Publication. 1999; 126 p.

19. Blaxhall PC, Daisley KW. Routine hematological methods for use with fish blood. J Fish Biol. 1973;5(6):771-781.

20. Krayushkina LS, Dyubin VP. Reaction of juvenile acipenserids on saline changes of environmental media. Questions of Ichthyology. 1974;14(6):1118-1124.

21. Farabi SMV, Hajimoradloo A, Bahmani M. Study on salinity tolerance and some physiological indicators of ion-osmoregulatory system in juvenile beluga, Huso huso (Linnaeus, 1758) in the south Caspian Sea: Effects of age and size. Iranian Journal of Fisheries Sciences. 2007;6(2):15-32.

22. Krayushkina LS. Level of development of osmoregulatory system of young sturgeons depends on size and age. In: Biological principles of sturgeon fish-farming. Barannikova IA, Berdichevski MA, editors. Moscow: Science: 1983a;158-166.
23. Martinez -Alvarezl RM, Hidalgo MC, Domezain A, et al. Physiological changes of sturgeon, Acipenser naccarii, caused by increasing environmental salinity. Journal of Experimental Biology. 2002;205:36993706 .

24. Schmidt-Nielsen K. Why is Animal Size So Important? Cambridge: Cambridge University Press. Stat Soft .1995; STATISTICA for Windows [Computer program manual]. Tulsa, Stat Soft, Inc. 1984; 186 p.

25. Calder WA. Size, Function and Life History. New York: Harvard University Press. 1984.60 p.

26. Nasri Tajan M, Zohrabi M. Determination of some hematological and biochemical parameters of Cultured Stellate sturgeon (Acipenser stellatus) and Ship sturgeon (Acipenser nudiventris) the changes age and Sex dependent. Iranian Journal of Fisheries Sciences. 2019; 13(2):125-137.

27. Chan DKO, Rankin JC, Chester Jones I. Influence of the adrenal cortex and the corpuscles of Stannis on osmoregulation in the European eel, Anguilla Anguilla L., adapted to fresh water. Gen comp Endocrinol. 1972; 2(2):342-53.

28. Mayer N, Maetz J, Chan DKO, et al. Cortisol, a sodium excretory factor in the eel (Anguilla anguilla L.) adapted to sea water. Nature. 1967;314:1118-1120.

29. Cataldi E, Di Marco P, Mandich A, et al. Serum parameters of Adriatic sturgeon Acipenser naccarii (Pisces: Acipenseriformes): effects of temperature and stress. Comp Biochem Physiology. 1998;121A(4):351354. 